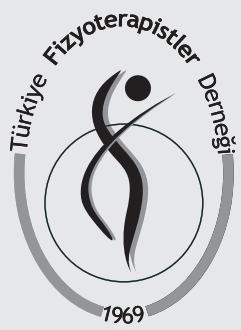

\section{Türk Fizyoterapi ve Rehabilitasyon Dergisi}

$201627(3) 116-120$

Selen SEREL ARSLAN, PT, PhD Ipek ALEMDAROǦLU, PT, PhD, Assist Prof'

Numan DEMIR, PT, PhD'

Aynur Ayşe KARADUMAN, PT, PhD, Prof $^{1}$

\title{
CLINICAL CHARACTERISTICS OF ORAL STRUCTURES AND FEEDING FUNCTION IN SUBACUTE SCLEROSING PANENCEPHALITIS
}

\section{RESEARCH ARTICLE}

\section{ABSTRACT}

Purpose: The aim was to investigate the characteristics of oral structures and feeding in patients with Subacute Sclerosing Panencephalitis (SSPE).

Methods: Twenty SSPE patients were included. Clinical evaluation of oral structures and oral hygiene were performed. Each patient was requested to take liquid, pudding and solid food consistencies during feeding evaluation. The Karaduman Chewing Performance Scale (KCPS) was used to determine the level of chewing function. The 3-ounce water swallow test was used to screen patients for aspiration risk.

Results: The mean age was $13.76 \pm 1.92$ years, of which $55 \%$ were male. Seven children (35\%) had open mouth posture at rest, 5 (25\%) had open bite, 12 (60\%) had high arched palate, and 8 $(40 \%)$ had tongue thrust. Eighteen children (90\%) had oral hygiene problems. Feeding positions were variable with 1 child fed in supine, 6 in semi-sitting position, and 13 in upright sitting position. Findings during clinical feeding evaluation revealed the following: food acceptance (20, $100 \%)$, liquid intake $(20,80 \%)$, pudding intake $(17,85 \%)$, and solid food intake $(5,25 \%)$. Five children (25\%) were in level I, 7 children (35\%) were in level II, 3 children (15\%) were in level III, and 5 children (25\%) were in level IV according to the KCPS. Four children (25\%) failed in 3 ounce water swallow test.

Discussion: Problems with oral structures, oral hygiene, chewing and swallowing function can be seen in SSPE patients. Thus, clinical oral structure and feeding functions should be considered to evaluate in routine evaluation procedure in patients with SSPE.

Key words: Subacute Sclerosing Panencephalitis; feeding; chewing; deglutition; deglutition disorders

\section{SUBAKUT SKLEROZAN PANENSEFALIT'DE ORAL YAPILARIN VE BESLENME FONKSIYONUNUN KLINIK ÖZELLIKLERi}

\section{ARAŞTIRMA MAKALESI}

\section{öz}

Amaç: Amaç, Subakut Sklerozan Panensefalit (SSPE)'li hastalarda oral yapıların ve beslenme özelliklerinin incelenmesidir.

Geliş Tarihi: 22.08.2016 (Received) Kabul Tarihi: 01.12.2016 (Accepted)

İletişim (Correspondence):

Selen Serel Arslan, PT, PhD

(Corresponding author)

Hacettepe University, Faculty of Health

Sciences, Department of Physical

Therapy and Rehabilitation, Altındağ, 06100, Ankara, Turkey

Phone number: +905356643007

Fax number: +903123052012

Email: selen.serel@hacettepe.edu.tr

1 Hacettepe University, Faculty of Health Sciences, Department of Physical Therapy and Rehabilitation, Ankara, Turkey
Yöntemler: Yirmi SSPE hastası dahil edildi. Oral yapılar ve oral hijyenin klinik değerlendirmesi yapıldı. Beslenme değerlendirmesinde her hastadan sıvı, puding ve katı besin kıvamlarını alması istendi. Çiğneme fonksiyonu seviyesinin belirlenmesinde Karaduman Çiğneme Performansı Skalası (KÇPS) kullanıldı. Hastalarda aspirasyon riskini belirlemek için 3 ons su yutma testi kullanıldı.

Sonuçlar: Ortalama yaş $13.76 \pm 1.92$ yıldı ve \%55’i erkekti. Yedi çocukta (\%35) dinlenmede açık ağız postürü, 5 (\%25)'inde açık ısırık, 12 (\%60)'sinde yüksek damak, ve 8 (\%40)'inde dil itme refleksi vardı. Onsekiz (\%90) çocukta oral hijyen problemleri vardı. Beslenme pozisyonları; 1'i sırtüstü, 6'sı yarı yatış pozisyonu, ve 13'ü dik oturma pozisyonu olmak üzere farklılık göstermekteydi. Klinik beslenme değerlendirmesi sonuçlarımız şöyleydi: besin kabulü (20, $\% 100)$, sıvı alımı (20, \%80), puding alımı (17, \%85), ve katı besin alımı (5, \%25). KÇPS'ye göre 5 çocuk (\%25) seviye I, 7 çocuk (\%35) seviye II, 3 çocuk (\%15) seviye 3 ve 5 çocuk (\%25) seviye IV'idi. Üç ons su yutma testinde 4 çocuk (\%25) kaldı.

Tartışma: SSPE hastalarında oral yapılar, oral hijyen, çiğneme ve yutma fonksiyonunda problemler görülebilmektedir. Bu yüzden, SSPE hastalarının rutin değerlendirmesinde klinik oral yapı ve beslenme fonksiyonlarının değerlendirilmesi de düşünülmelidir.

Anahtar kelimeler: Subakut Sklerozan Panensefalit; beslenme; çiğneme; yutma; yutma bozuklukları 


\section{INTRODUCTION}

Subacute sclerosing panencephalitis (SSPE) is a rare, progressive, and long-term complication of measles infection, which results in a neurodegeneration in the central nervous system (1). The disease incidence varies in different countries according to the routine immunization policies of the countries (2-5). For instance, the disease is seen as 0.01 per million in the USA (2), 0.06 per million in Canada (3), 0.461 per million in Turkey (4), and 11 per million in Japan (5). The incidence of SSPE is relatively high in our country depending on the measles virus vaccination (4).

SSPE is not easily treated disease due to progressive characterization of the clinical findings (6). The course of the disease were reported to be variable: $10 \%$ of cases with more severe prognosis resulting in death within a few months after onset, $10 \%$ with a protracted prognosis from 4 to 10 years after the onset (7).

Changes in muscle tones, recurrent falls, behavioral changes, progressive intellectual deterioration, seizures were reported as the most frequent symptoms of the disease (1). SSPE may occur at any age, but most commonly in school age with normal neurological and behavioral status until clinical symptoms arise (8). While the disease progresses, motor weakness, increased tonus, and myoclonic jerks become visible. Gradual loss of ambulation and speech, respiratory problems, cardiovascular impairment may also be seen during the disease progress. Bulbar dysfunction was reported to be the most life-threatening condition (8). A number of studies mentioned that feeding and swallowing problems might occur in later stages of SSPE $(9,10)$. However, no study was performed to investigate the characteristics of oral structures and feeding of patients with SSPE. Our study was aimed to investigate the clinical characteristics of oral structures and feeding function in SSPE patients.

\section{METHODS}

This cross-sectional study was performed in Hacettepe University, Faculty of Health Sciences, Physiotherapy and Rehabilitation Department. The ethical approval was obtained from Hacettepe University, Non-Invasive Clinical Research Ethics Committee.
All of the patients and their parents signed the written consent forms to participate the study.

The inclusion criterias were as follows; a) diagnosis with SSPE by a neurologist, b) age between 4-18 years, c) complaints about feeding function. Exclusion criterios were: a) no complaints about feeding, b) no use of medicine/oral appliances that could affect the feeding function.

The demographic characteristics including age (year), height $(\mathrm{cm})$, weight $(\mathrm{kg})$, age at diagnosis (year) were recorded. Functional motor level of the patients was scored as ambulatory or non-ambulatory.

The impairments such as open mouth posture at rest, open bite, high arched palate and tongue thrust were assessed and scored as absent or present during clinical oral structure evaluation. The presence of spontaneous opening of the lips at rest is considered as open mouth posture at rest, inability to meet the upper and lower incisors as open bite, unusually high and narrow palate as high arched palate, and tongue protrusion through the anterior incisors during swallowing as tongue thrust (11).

Oral hygiene evaluation was performed by observing the ability of the child to keep the mouth and teeth clean. The daily feeding position which parents prefered for their child were asked to the parents and noted. Observational analysis was performed for clinical feeding evaluation. Each child was placed in a sitting position (on a chair) with the head upright and midline position, and the arms and legs supported. Each child was requested to take a standardized liquid, pudding and solid food consistency during feeding evaluation. The food acceptance, food spillage, and the consistencies that the child could manage were first noted. The Karaduman Chewing Performance Scale (KCPS) which is a valid, reliable, quick, and clinically easy to use tool was used to determine the level of chewing function. The KCPS classifies the chewing function between 0-4. "0" means normal chewing function, and "4" means no biting and chewing (12).

The 3-ounce water swallow test was used to screen patients for aspiration risk. It is a widely used screening method which is 100\% sensitive for determining aspiration of thin liquids and 100\% sensitive 
for identifying individuals deemed safe for oral intake $(13,14)$. A swallowing therapist administered the 3-ounce water swallow test in this study. Each patient was given 3 ounces of water and asked to drink from a cup or straw without interruption, and results were noted. Criteria for test failure were the inability to drink the entire amount, coughing or choking up to 1 min after completion, or presence of post-swallow wet-hoarse vocal quality (14). It was also reported that if the 3-ounce water swallow protocol is passed, not only thin liquids but diet recommendations with puree and solid food consistencies can be made for children without the need for further instrumental dysphagia testing (14).

\section{Statistical analysis}

Statistical analysis was performed by using IBMSPSS for Windows version 20. Descriptive statistics were calculated as number/percent $(n / \%)$ for categorical data and mean \pm standard deviation for continuous data.

\section{RESULTS}

Twenty SSPE patients were included. The demographic characteristics of the patients are shown in Table 1. Fourty-five percent of the patients $(n=9)$ were female and $55 \%(n=11)$ were male. Sixteen children (80\%) were found to be non-ambulatory while remaining were ambulatory.

Tablo 1. Demographic characteristics of the SSPE patients $(\mathrm{n}=20)$

\begin{tabular}{|l|c|c|c|}
\hline & Min & Max & X \pm SD \\
\hline Age (year) & 11 & 18 & $13.76 \pm 1.92$ \\
\hline Height $(\mathrm{cm})$ & 135 & 170 & $150 \pm 14.72$ \\
\hline Weight $(\mathrm{kg})$ & 28 & 45 & $37 \pm 6.08$ \\
\hline Age at diagnosis (year) & 4 & 15 & $7.94 \pm 3.17$ \\
\hline
\end{tabular}

The distribution of oral structural impairments of the patients is presented in Table 2. Ninety percent $(n=18)$ of the patients had oral hygiene problems.

Tablo 2. Clinical oral structural problems of the patients $(n=20)$

\begin{tabular}{|l|c|}
\hline Impairments in oral structure & $\mathbf{n ~ ( \% )}$ \\
\hline Open mouth & $7(35)$ \\
\hline Open bite & $5(25)$ \\
\hline High arched palate & $12(60)$ \\
\hline Tongue thrust & $8(40)$ \\
\hline
\end{tabular}

Feeding positions were variable with 1 child fed in supine, 6 in semi-sitting position, and 13 in upright sitting position. Findings during clinical feeding evaluation are shown in Table 3.

Tablo 3 . The results related to the feeding evaluation of patients $(n=20)$

\begin{tabular}{|l|c|}
\hline $\begin{array}{l}\text { Parameters of feeding } \\
\text { assessment }\end{array}$ & n (\%) \\
\hline Food acceptance & $20(100)$ \\
\hline Food spillage & $16(80)$ \\
\hline Liquid intake & $20(100)$ \\
\hline Pudding intake & $17(85)$ \\
\hline Solid food intake & $5(25)$ \\
\hline
\end{tabular}

Five children (25\%) were in level I, 7 children (35\%) were in level II, 3 children (15\%) were in level III, and 5 children (25\%) were in level IV according to the KCPS.

Four children (25\%) failed in 3 ounce water swallow test.

\section{DISCUSSION}

SSPE is a rare disease, which has four main stages during disease progression. Swallowing dysfunction was reported to be seen in the last stage of the disease (9). Due to the infrequency of the disease, literature about SSPE included only case studies and a limited number of reviews $(9,10,15-$ 18). However, no study was encountered to show the clinical features of oral structures, and feeding function of this patient population in literature. It is important to define feeding dysfunction in SSPE population because the poor nutrition becomes a problem due to chewing and swallowing problems during disease progression. In this study, $60 \%$ of the study population was found to have high arched palate, $40 \%$ tongue thrust, $35 \%$ open mouth posture at rest and $25 \%$ open bite in terms of oral structure evaluation. Ninety-percent of the patients had oral hygiene problems and $80 \%$ had food spillage from the mouth during feeding. All patients had liquid intake while $85 \%$ took puding consistency and only $25 \%$ had solid food intake. Twenty percent of all SSPE patients failed in 3 ounce water swallow test.

Patients with neurological impairments are known to have problems related to oral structure (19-21). For instance, children with cerebral palsy were 
shown to have significantly increased overjet and overbite and were likely to have incompetent lips (20). The most commonly cited impairments in children with neurologic disorders are poor lip closure and tongue movements (21). It is important to define oromotor impairments because the problems in oral structures can be associated with the problems in oral functions related to the effected structure. According to the findings of our study, oral structures were problematic in SSPE patients which may cause oromotor dysfunction due to oromotor impairments at any time of the disease progress.

Oral hygiene is the ability of the child to keep the mouth and teeth clean (22). Efficient lip, tongue, palate function is necessary for keeping the mouth and teeth clean, and prevent food spillage from mouth. Many studies noted an association between open mouth posture, tongue thrust and uncontrolled food spillage from mouth $(23,24)$. Thus, we may explain the oral hygiene problems and food loss during feeding in our patient population with the presence of open mouth and open bite posture with insufficient tongue functions.

Chewing function is a rhythmic oral motor activity designed to comminute and soften solid foods with biting food with central incisors, transporting food from the front of the mouth to the molar area by using the tongue, and grinding and softening the food via a series of masticatory cycles (25). Once this sequence is interrupted, chewing function can not be managed and solid food intake may decrease. In our study, patients were found to have difficulty in solid food intake which was also shown with the KCPS. There were no children in level 0 which means normal chewing function. Only five children were in level I which means "The child chews but there are some difficulties in transition food to bolus" (12). The remaining children dispersed in levels II, III and IV which indicated chewing dysfunction. Likewise oral hygiene problems and food loss from the mouth, presence of high arched palate, open mouth posture and bite posture, and insufficient tongue functions may also cause an inability to manage solid food in SSPE patients because these impairments may interrupt the sequence of chewing function. This finding is important because the diet of children with normal feeding skills includes liquid, semisolid and/or solid foods together so unable to take any solid food may affect the sufficient food intake and nutritional status of this patient population.

Three ounce water swallow test was used as a screening test for determination the children with suspected oropharyngeal dysphagia (14). Four patients failed in 3 ounce water swallow test. Failure was due to coughing or inability to consume the entire 3 ounces of water. These findings will be life-threatening problem due to the potential risk of aspiration pneumonia. Thus, although 3 ounce water swallow test allows greater objective identification of aspiration, an instrumental swallowing evaluation to assess pharyngeal swallowing disorder should be performed.

This study is the first study to define the clinical characteristics of oral structures and feeding function in patients with SSPE. There are also some limitations to this current study. The study can not differentiate the clinical characteristics of oral structures and feeding function of children with SSPE according to their motor functional level. Thus, although SSPE is a rare disease, the sample size will be increased and the differences between children according to their motor functional levels will be investigated in terms of oral structures and feeding functions. Instrumental swallowing evaluations should also be added to support current findings.

\section{CONCLUSIONS}

Our study contributes to the need of the assessment of oral structures, feeding and swallowing function with the results such as the presence of oromotor impairments, oral hygiene problems, food spillage from the mouth during feeding, problem in solid food intake and the risk of aspiration during swallowing in SSPE patient population. The results of this current study is important to increase the awareness of the clinicians and families in terms of feeding and swallowing dysfunction in SSPE population because poor nutrition due to feeding and swallowing dysfunction becomes a problem during disease progression. 


\section{REFERENCES}

1. Garg RK, Anuradha HK, Varma R, Singh MK, Sharma PK. Initial clinical and radiological findings in patients with SSPE: are they predictive of neurological outcome after 6 months of follow-up?. J Clin Neurosci. 2011;18(11):1458-62.

2. Singer C, Lang AE, Suchowersky O. Adult-onset subacute sclerosing panencephalitis: case reports and review of the literature. Mov Disord. 1997;12(3):342-53.

3. Campbell C, Levin S, Humphreys P, Walop W, Brannan R. Subacute sclerosing panencephalitis: results of the Canadian Paediatric Surveillance Program and review of the literature. BMC Pediatr. 2005;5:47.

4. Anlar B, Köse G, Gürer Y, Altunbaşak S, Haspolat S, Okan M. Changing epidemiological features of subacute sclerosing panencephalitis. Infection. 2001;29(4):192-5.

5. Campbell H, Andrews N, Brown KE, Miller E. Review of the effect of measles vaccination on the epidemiology of SSPE. Int J Epidemiol. 2007;36(6):1334-48.

6. Chiu MH, Meatherall B, Nikolic A, Cannon K, Fonseca K, Joseph JT, et al. Subacute sclerosing panencephalitis in pregnancy. Lancet Infect Dis. 2016;16(3):366-75.

7. Honarmand S, Glaser CA, Chow E, Sejvar JJ, Preas CP, Cosentino GC, et al. Subacute sclerosing panencephalitis in the differential diagnosis of encephalitis. Neurology. 2004;63(8):1489-93.

8. Anlar B. Subacute sclerosing panencephalitis and chronic viral encephalitis. In: Dulac O, Lassonde M, Samat HB, editors. Handbook of clinical neurology. Elsevier, 2013; p. 1183-9.

9. Nguefack S, Ngoh R, Demanou M, Chiabi A, Mah E, Mbassi Awa $\mathrm{H}$, et al. Subacute Sclerosing Panencephalitis: A typical case but nearly misdiagnosed. Health Sci Dis. 2015;16(2):1-4.

10. Cruzado D, Masserey-Spicher V, Roux L, Delavelle J, Picard F, Haenggeli CA. Early onset and rapidly progressive subacute sclerosing panencephalitis after congenital measles infection. Eur J Pediatr. 2002;161(8):438-41.

11. Logemann JA. Anatomy and physiology of normal deglutition. In: Logeman JA, editor. Evaluation and treatment in swallowing disorders. Texas: Pro-ed; 1998; p. 13-52.

12. Serel Arslan S, Demir N, Barak Dolgun A, Karaduman AA. Development of a new instrument for determining the level of chewing function in children. J Oral Rehabil. 2016;43(7):488-95.

13. Suiter DM, Leder SB. Clinical utility of the 3-ounce water swallow test. Dysphagia. 2008;23(3):244-50.

14. Suiter DM, Leder SB, Karas DE. The 3-ounce (90-cc) water swallow challenge: a screening test for children with suspected oropharyngeal dysphagia. Otolaryngol Head Neck Surg. 2009;140(2):187-90.

15. Gutierrez J, Issacson RS, Koppel BS. Subacute sclerosing panencephalitis: an update. Dev Med Child Neurol. 2010;52(10):901-7.

16. Teber S, Sezer T, Kafalı M, Deda G. Subacute sclerosing panencephalitis with an atypical presentation: A case report. J Pediatr Neurol. 2011;9(1):127-30.

17. Rana M, Rana VM, Singh A, Singhal S. Subacute sclerosing panencephalitis: A rare neurological disorder in pregnancy. JEMDS. 2015;4(23):4033-6

18. Garg RK. Subacute sclerosing panencephalitis. Postgrad Med J 2002;78:63-70.

19. Benfer KA, Weir KA, Bell KL, Ware RS, Davies PSW, Boyd RN. Oropharyngeal dysphagia in preschool children with cerebral palsy: Oral phase impairments. Res Dev Disabil. 2014;35(12):346981.

20. Franklin DL, Luther F, Curzon MEJ. The prevalence of malocclusion in children with cerebral palsy. Eur J Orthod. 1996;18(6):63743.

21. Ortega Ade O, Ciamponi AL, Mendes FM, Santos MT. Assessment scale of the oral motor performance of children and adolescents with neurological damages. J Oral Rehabil. 2009:36(9):653-9.

22. World Health Organization [homepage on the Internet]. Health topics: Oral health [updated 2015 March 6]. Available from: http://www.who.int/topics/oral_health/en/

23. Gisel EG. Oral-motor skills following sensorimotor intervention in the moderately eating-impaired child with cerebral palsy. Dysphagia. 1994;9(3):180-92.

24. Lespargot A, Langevin MF, Muller S, Guillemont S. Swallowing disturbances associated with drooling in cerebral-palsied children. Dev Med Child Neurol. 1993;35(4):298-304.

25. Hiiemae K. Mechanisms of food reduction, transport and deglutition: how the texture of food affects feeding behavior. J Texture Stud. 2004;35(2):171-200. 